\title{
SHORT-TERM STUDY IN FOREIGN SPECIALIZED CENTERS AND MEDICAL UNIVERSITIES AS WAY OF REFORMS IMPLEMENTATION IN PRACTICAL MEDICINE
}

\author{
Bachynskiy V. ${ }^{1}$, Truebner K. ${ }^{2}$, Vanchuliak O. ${ }^{1}$, Savka I. ${ }^{1}$, Garazdiuk M. ${ }^{1}$ \\ ${ }^{1}$ Higher State Educational Establishment of Ukraine "Bukovinian State Medical University", \\ Forensic Medicine and Medical Law Department, Ukraine; \\ ${ }^{2}$ Duisburg-Essen University, Institute of Forensic Medicine, Federal Republic of Germany
}

\begin{abstract}
The processes of European integration of Ukraine have led to the need for reforming all spheres of life of the state and its society, including a higher school. Therefore, the reorganization of higher education in Ukraine on the basis of a new definition of the role and function of a teacher, the implementation of the practice of state sectoral programs requires the restructuring of educational approaches in the context of the requirements and capabilities of today. Since the adoption of the law on academic mobility, such a form of improving pedagogical skills as short-term study, has become very popular among high school teachers. As an example the article provides a short-term study of teachers of the Department of Forensic Medicine and Medical Law of Higher State Educational Establishment of Ukraine "Bukovinian State Medical University" in Institute of Forensic Medicine in Federal Republic of Germany.
\end{abstract}

Key words: short-term study, higher medical school, teacher.

The processes of European integration of Ukraine have led to the need for reforming all spheres of life of the state and its society. Higher school was no exception, as it forms new standards and forms of training for future specialists who will implement innovations. In addition to a high level of competence and professionalism, they must engage in self-training and seek to master the latest developments for their introduction to innovation and creative work at the appropriate scientific and practical level. Therefore, the reorganization of higher education in Ukraine on the basis of a new definition of the role and function of a teacher, the implementation of the practice of state sectoral programs requires the restructuring of educational approaches in the context of the requirements and capabilities of today. The system of training high school staff is aimed at solving this issue through constant self-development and self-education of the teacher throughout his life. One of the effective ways of improving professional, pedagogical and practical skills is an short-term study aimed at replenishing of pedagogical experience, exchange and participation in the development of educational and methodological materials, acquaintance with the latest technologies of teaching, achievements of science and technology in the field of education.

Since the adoption of the law on academic mobility, such a form of improving pedagogical skills as short-term study, has become very popular among high school teachers, it is advisable to specify that there are several types of short- term study: pedagogical, subject-professional and scientific. If teacher training is aimed at improving teaching skills, the ability to efficiently performing work with young people, the subject-professional ones aims to deepen and improve the teaching of a particular subject, improving knowledge and skills in certain professions. Recently, a kind of scholarly type of short-term study has begun to be distinguished, which ones in principle includes the subject-professional, but has a much deeper foundation, which allows to combine the educational process, research activities and scientific progress.

"Regulations on the implementation of the right to academic mobility", approved by the Resolution of the Cabinet of Ministers of Ukraine dated August 12, 2015, No. 579 [1], promotes the practical implementation of bilateral educational exchanges including internships that allows Ukraine to enter a new educational and scientific level in the process of European integration. This document is closely linked to the Order of the Ministry of Education and Science of Ukraine No. 13 dated January 14, 2016. [2] According to the new Order of the assignment of scientific degrees to scientific and scientific and pedagogical workers (Order of the Ministry of Education and Science of Ukraine of January 14, 2016, No. 13 as amended on 06.02.2017, No. 174, registered with the Ministry of Justice of Ukraine on 02.22.2017) by one from the requirements for conferring the academic title of associate professor or professor is a short-term study in a higher educational institution or a scientific (or scientific and technical) institution in a country which is a member of the Organization for Economic Cooperation or the European Union and holds appropriate certificates, diplomas or other documents which confirm it's. [2,3]. These two normative and legal documents encourage higher education teachers not only to obtain a degree, but also to increase their scientific and practical level, which enables them to achieve European recognition and rank in line with the leading scholars of the world. Interestingly that in the vast majority of European countries departments of medical universities are represented by institutes at clinics, which enables teachers to continuously perform practical medical work. Accordingly teachers who have the short-term study in these institutions have even more opportunities to improve their professionalism for further introduction of the latest technologies into the national educational and practical activities.

For example, we will present the experience of the teachers of the Department of Forensic Medicine and Medical Law of the Higher State Educational Establishment of Ukraine "Bukovinian State Medical University" who have recently returned from the Federal Republic of Germany (FRG), where they had a short-term study at the Institute of Forensic Medicine (FM) at 
Duisburg-Essen University. Since they are directly experts of the Bureau of forensic medical examination, they were interested in the pedagogical subtleties of European teaching in higher education and the peculiarities of the performance of forensic examination in comparison with the domestic service.

There is a bureau of forensic medical examination in each region in Ukraine where the burden on the expert per year is a constant figure, according to which the general number of expert is calculated. In Germany, the population is approximately 80 million inhabitants living in 16 federal lands, in which 29 forensic medicine institutes are located (21 belong to universities, 3 to federal landed (in Bremen, Potsdam and Berlin), the rest are small private institutions accredited to certain type of activities). One institute serves 3.3 million inhabitants on average. Three Federal Land Institutions work with local health authorities. They are directly subordinate to the Ministry of Health and are analogues of our Bureau of FM.

The training of a forensic expert is also different from domestic ones [4,5]. In Ukraine, it represents 1.5 years of internship, whereas in the FRG the conditions for admission to the certification for the specialty "forensic medicine" are the availability of 42 months of continuous work experience at the Institute of Forensic Medicine (at least 300 sections must be held), 12 months internship in the Institute of Pathological Anatomy (at least 100 sections) and 6 months in the Department of Forensic Psychiatry (at least 30 forensic psychiatric examinations) with mandatory participation in court sessions. In general, the training program lasts about 5 years.

After obtaining the diploma the expert is obliged to take part in conferences, seminars for obtaining points for further licensing. Scientific work, publication of articles and speeches at conferences are approved, since they allow to score more points, as an expert can not be accredited without enough points.

FM institutes are usually accredited in the following areas (have the following departments):

- $\quad$ FM tanatology (carrying out autopsy) and the investigation of living persons.

- $\quad$ FM histology.

- $\quad$ FM molecular genetics (parenting, identity and material evidence).

- $\quad$ FM toxicology and assessment of alcohol (definition of alcohol, drugs and potent substances).

Private clinics of SM expertise, as a rule, conduct simple autopsies, investigation of living persons, laboratory examinations, determination of the content of alcohol, psychoactive substances.

All the staff of the forensic medical experts including the directors of the institutes participate in the alternate visits to the scene of death, which is clear when there are only 3 doctors in the state of the institute, including a professor (Greifswald in Pomerania). Usually, experts are on duty at home with departure to the scene of death if it is necessary.

One of the most important points of expert work is a work in court. Virtually all cases of death of violent genesis and all researches of living persons have to be discussed in a court by an expert with a protection of the received data. One expert accounts for about 50 court sessions a year, that is approximately one per week.

A load on 1 post is absent, but the average load on the number of examinations per year is as follows:

1) department of FM toxicology - near 1200 examinations per year per 1 staff unit of toxicology expert; 2)department of FM genetics - near 40-60 examinations per year per 1 staff unit of an expert immunologist; 3)department of FM criminalistics - near 60 examinations per year per 1 expert;

4) department of FM histology - 20-30\% of all autopsies;

5) department of FM examinations of corpses - near 100 examinations per year for 1 position of city expert; FM examinations of victims, accused and other persons - 20-30 examinations per year per 1 expert.

The staff of the 21 institutes of Germany conduct teaching work at the universities. Practical classes are held in small groups (8-10 people) twice a week. The study program and the form of student knowledge control is determined by the university at its discretion in the form of testing, practical work in the laboratory and an autopsy.

The work of FM departments is somewhat different from domestic ones. Certification of living persons in respect of injuries sustained is usually carried out by a regular doctor in the hospital but not by the FM expert. Forensic expert is called only in special cases, and special departments of examination of living persons are not foreseen. An expert examination is carried out by an expert at the time of duty and no more than 1-2 times a month in one of the city clinics or in the regular unit of the police.

One of the main types of work of the domestic forensic expert - the definition of the severity of bodily injuries - is absent in Germany. Qualification of injuries by severity is carried out by lawyers. If it is necessary, for the clarifications of certain issues doctors or forensic physicians are called to the court. They advise the court on medical matters, do not take decisions on the degree of severity and answer exclusively on medical questions. Regarding the examination of corpses cases of violent death are not always carried out (in many cases the computer tomography of the corpse is preferred). In particular, such cases occur in suicides and road accidents.

As for forensic criminal investigations: the fingerprint examination, the authentication of documents is beyond the competence of forensic experts. Fiber research, trasology and ballistic expertise are under the jurisdiction of the State Forensic Police Service (analogous to the domestic Scientific-Research Experimental Forensic Center)..

The financing and payment of the Forensic Service is carried out at the expense of the budget of the Land Prosecutor's Office. The staff of the institutes is additionally funded by the universities they are staffed with. In Germany the payment for a section depends on its complexity, which is determined by the necessity and amount of additional research, the presence of pronounced putrefaction, etc. 


\title{
Conclusions
}

1. Short-time study plays an important role both in pedagogical formation and in the practice of teachers of medical universities.

2. It should also take into account the need to create scientific and practical centers forensic medical examination on the basis of relevant departments of medical universities and bureau in the regions, where possible. Structural units in the form of regional bureau should be left only in those areas where there are no conditions for the establishment of the above-mentioned centers (there are no specialized universities). In carrying out the structural reorganization of forensic medical examination in Ukraine, it is also necessary to include in the working group specialists from the Supreme Court of Ukraine, the General Prosecutor's Office of Ukraine and the Ministry of Internal Affairs and Justice to settle all work issues and jointly develop a concept for the development of forensic medical examination of Ukraine in the context of dynamic changes regulatory and legal framework and law enforcement reform in Ukraine.

3. The autonomy of forensic institutions allows you to receive funding from several sources, as well as to provide privatelypaid services that allow the development of the service and improve the level of expertise.

4. After the general introduction and implementation of structural and methodological changes in the reform of the Forensic service in the future, one should abandon any loads per one staff unit as those that are contrary to world experience.

\section{Література}

1. Положення про порядок реалізації права на академічну мобільність. Постанова Кабінету Міністрів України від 12 серпня 2015 № 579 [Інтернет]. Київ: КМУ; 2015 [цитовано 2018 Лют 18]. Доступно: https://zakon.rada.gov.ua/laws/show/579-2015-\%D0\%BF\#Text

2. Про затвердження Порядку присвоєння вчених звань науковим і науково-педагогічним працівникам. Наказ МОН України від 14 січня 2016 № 13 [Інтернет]. Київ: МОН України; 2016 [цитовано 2018 Лют 18]. Доступно: https://zakon.rada.gov.ua/laws/show/z0183-16\#Text

3. Про внесення змін до Порядку присвоєння вчених звань науковим і науково-педагогічним працівникам. Наказ МОН України від 6 лютого 2017 № 174 [Інтернет]. Київ: МОН України; 2017 [цитовано 2018 Лют 18]. Доступно: https://zakon.rada.gov.ua/laws/show/z0245-17\#Text

4. Schwerd W, Gustav A. Kurzgefaßtes Lehrbuch der Rechtsmedizin für Mediziner und Juristen. Köln-Lövenich: Deutscher Aerzte-Verlag; 1979. 377 s.

5. Deutsche Gesellschaft für Rechtsmedizin [Internet]. DGRM; 2009 [updated 2009 Mar 23; cited 2018 Feb 12]. Available from: https://www.dgrm.de/

\section{References}

1. Polozhennia pro poriadok realizatsii prava na akademichnu mobil'nist' [Regulations on the procedure for exercising the right to academic mobility]. Postanova Kabinetu Ministriv Ukrainy vid 12 serpnia 2015 № 579 [Internet]. Kyiv: KMU; 2015 [tsytovano 2018 Liut 18]. Dostupno: https://zakon.rada.gov.ua/laws/show/579-2015-\%D0\%BF\#Text (in Ukrainian)

2. Pro zatverdzhennia Poriadku prysvoiennia vchenykh zvan' naukovym i naukovo-pedahohichnym pratsivnykam [About the statement of the Order of assignment of scientific ranks to scientific and scientific and pedagogical workers]. Nakaz MON Ukrainy vid 14 sichnia 2016 № 13 [Internet]. Kyiv: MON Ukrainy; 2016 [tsytovano 2018 Liut 18]. Dostupno: https://zakon.rada.gov.ua/laws/show/z0183-16\#Text (in Ukrainian)

3. Pro vnesennia zmin do Poriadku prysvoiennia vchenykh zvan' naukovym i naukovo-pedahohichnym pratsivnykam [About modification of the Order of assignment of scientific ranks to scientific and scientific and pedagogical workers]. Nakaz MON Ukrainy vid 6 liutoho 2017 № 174 [Internet]. Kyiv: MON Ukrainy; 2017 [tsytovano 2018 Liut 18]. Dostupno: https://zakon.rada.gov.ua/laws/show/z0245-17\#Text (in Ukrainian)

4. Schwerd W, Gustav A. Kurzgefaßtes Lehrbuch der Rechtsmedizin für Mediziner und Juristen. Köln-Lövenich: Deutscher Aerzte-Verlag; 1979. 377 s.

5. Deutsche Gesellschaft für Rechtsmedizin [Internet]. DGRM; 2009 [updated 2009 Mar 23; cited 2018 Feb 12]. Available from: https://www.dgrm.de/

\section{СТАЖУВАННЯ В ЗАКОРДОННИХ СПЕЦІАЛІЗОВАНИХ ЦЕНТРАХ ТА МЕДИЧНИХ УНІВЕРСИТЕТАХ ЯК ШЛЯХ ВПРОВАДЖЕННЯ РЕФОРМ У ПРАКТИЧНУ МЕДИЦИНУ}

\author{
Бачинський В., Трюбнер К., Ванчуляк О., Савка І., Гараздюк М.
}

Резюме. Процеси європейської інтеграції України привели до необхідності реформування всіх сфер життя держави та іiі суспільства, у тому числі вищої школи. Тому реорганізація вищої освіти в Україні на основі нового визначення ролі та функції 
вчителя, здійснення практики державних галузевих програм потребує перебудови освітніх підходів у контексті сучасних вимог та можливостей. 3 часу прийняття закону про академічну мобільність така форма вдосконалення педагогічних навичок як стажування стала дуже популярною серед викладачів вищої школи. Як приклад, у статті наводиться стажування викладачів кафедри судової медицини та медичного правознавства Вищого державного навчального закладу України «Буковинський державний медичний університет» в інституті судової медицини Федеральної Республіки Німеччина.

Ключові слова: стажування, вища медична школа, викладач.

\title{
СТАЖИРОВКА В ЗАРУБЕЖНЫХ СПЕЦИАЛИЗИРОВАННЫХ ЦЕНТРАХ И МЕДИЦИНСКИХ УНИВЕРСИТЕТАХ КАК ПУТЬ ВНЕДРЕНИЯ РЕФОРМ В ПРАКТИЧЕСКУЮ МЕДИЦИНУ
}

\author{
Бачинский В., Трюбнер К., Ванчуляк О., Савка І., Гараздюк М.
}

Резюме. Процессы европейской интеграции Украины привели к необходимости реформирования всех сфер жизни государства и его общества, в том числе и высшей школы. Поэтому реорганизация высшего образования в Украине на основе нового определения роли и функции преподавателя, реализация практики государственных секторальных программ требует перестройки образовательных подходов в контексте требований и возможностей сегодняшнего дня. С момента принятия закона об академической мобильности такая форма совершенствования педагогических навыков, как стажировка, стала очень популярной среди учителей высшей школы. В качестве примера в статье представлена стажировка преподавателей кафедры судебной медицины и медицинского правоведения Высшего государственного образовательного учреждения Украины «Буковинский государственный медицинский университет» в институте судебной медицины в Федеративной Республике Германия.

Ключевые слова: стажировка, высшая медицинская школа, преподаватель. 